\title{
Localization of preproenkephalin mRNA-expressing cells in rat auditory brainstem with in situ hybridization
}

\author{
Douglas W. Hoffman a,b, Jill S. Hochreiter a , Douglas R. Landry a,b, Megan R. Brimijoin ${ }^{\mathrm{a}}$, \\ Melinda D. Treadwell b ${ }^{\mathrm{b}}$, Paul D. Gardner ${ }^{\mathrm{c}}$ and Richard A. Altschuler ${ }^{\mathrm{d}}$ \\ Departments of a Psychiatry, ${ }^{b}$ Pharmacology, and ${ }^{c}$ Biochemistry, Dartmouth Medical School, Hanover, New Hampshire and \\ ${ }^{d}$ Kresge Hearing Research Institute, University of Michigan, Ann Arbor, Michigan, USA
}

(Received 25 August 1992; Revision received 29 March 1993; Accepted 2 April 1993)

\begin{abstract}
Hair cells and auditory nerve dendrites in the inner ear are innervated by pontine neurons that have been demonstrated by immunochemical techniques to contain several neurotransmitters, including acetylcholine and the opioid peptide enkephalins and dynorphins. The functions of these nerve fibers are not known, but may involve modifying auditory sensitivity to low intensity stimuli. In the guinea pig the opioid pathways originate in the lateral superior olivary region. A recent study in the gerbil has reported cells expressing preproenkephalin mRNA present only in the ventral nucleus of the trapezoid body, and not in the superior olivary region. In the present study, a non-radioisotopically labeled in situ hybridization method was used to identify cells expressing mRNA coding for preproenkephalin in rat pontine neurons, specifically in the ventral nucleus of the trapezoid body. These cells may represent an enkephalin-containing medial olivocochlear system in the rat, the origin of the lateral system in the rat that differs markedly from the better-studied guinea pig and cat, or a non-olivocochlear enkephalin-containing system.
\end{abstract}

Olivocochlear; Auditory efferent; Trapezoid body; Superior olive

\section{Introduction}

A primary site of regulation of cellular function is at the level of gene expression. Such cellular regulation can be studied using the technique of in situ hybridization, in which the messenger RNA (mRNA) coding for specific proteins can be visualized in an individual cell or cell group. The short half life of mRNAs in cells defines the time frame of these observations, and so permits the visualization of genes currently being transcribed in response to functional requirements of an individual cell. In comparison to immunochemical methods, in which the binding site or antigenic determinant is usually 4-8 amino acids, these molecular biological techniques can involve binding of a thousand complementary base-pairs or more, and so provide a stronger, clearer and more specific signal than can be obtained with immunochemical methods. The specificity of the genetic code reduces problems of cross-reactivity common to immunochemical methods.

The fibers arising in the region of the pontine superior olivary and periolivary nuclei and terminating in the organ of Corti were first described by Rasmussen

Correspondence to: Douglas W. Hoffman, Neurochemistry Laboratory, Department of Psychiatry, Dartmouth Medical School, Lebanon, NH 03756, USA.
(Rasmussen, 1942, 1946). These fibers were later reclassified by Warr and Guinan (Guinan et al., 1983, 1984; Warr 1980; Warr and Guinan, 1979) into 'medial' and 'lateral' systems based upon the location of their brain stem cells of origin and their cochlear sites of termination. It has become clear that there are anatomically and chemically distinct efferent systems innervating the cochlea; the lateral system, which terminates on eighth nerve dendrites under inner hair cells, and the medial, which directly innervates outer hair cells. In the rodent, the lateral efferent fibers project ipsilaterally to radial type I afferent dendrites within the inner hair cell (IHC) region. Medial olivocochlear neurons project bilaterally to the basal and circumnuclear regions of the outer hair cells (OHCs) with predominantly crossed fibers (Liberman and Brown, 1988; Warr et al., 1986; Winter et al., 1989).

There are both similiarities and differences in the neurochemistry of the lateral and medial olivocochlear efferent systems. The lateral efferents are reported to contain enkephalins, dynorphins, calcitonin gene-related peptide, acetylcholine (ACh), catecholamines and gamma-aminobutyric acid (GABA), while in the medial system ACh and GABA have so far been identified as putative transmitters (reviewed by Altschuler and Fex, 1986; Eybalin and Pujol, 1989; see also Adams et al., 1987; Lu et al., 1988).

The functions of the two efferent systems are not clear at this time. Much of the research on olivo- 
cochlear function has focused on the medial efferents, which are more accessible for stimulation and recording. The exact roles of the efferent olivocochlear systems in audition are presently unknown, although several functions have been suggested based on these systems' inhibitory activity (Art and Fettiplace, 1984; Fex, 1968; Gifford and Guinan, 1987; Guinan and Gifford, 1988a,b,c; Liberman, 1988, 1989, 1991; Rajan and Johnstone, 1988; Wiederhold, 1986; Winslow and Sachs, 1987). This laboratory has recently demonstrated that the opioid peptides in the lateral olivocochlear pathways appear to have profound effects in increasing the amplitudes of auditory evoked potentials and enhancing auditory sensitivity to low intensity stim- uli (Sahley et al., 1991). These results suggest a potentially important role for the lateral innervation in auditory function.

Recently, Ryan et al. (1991) reported the presence of enkephalin mRNA-expressing cells in the ventral nucleus of the trapezoid body of the gerbil but not in the lateral superior olive. This work raises the question of the origin of 'lateral' efferents in different species of rodents, or whether the lateral system is enkephalinergic in all species. We have applied a nonradioisotopic molecular biological technique to provide a more clear answer to the cellular localization of neurotransmitters than can be obtained with multiple immunocytochemical experiments or with autoradiographic in situ meth-
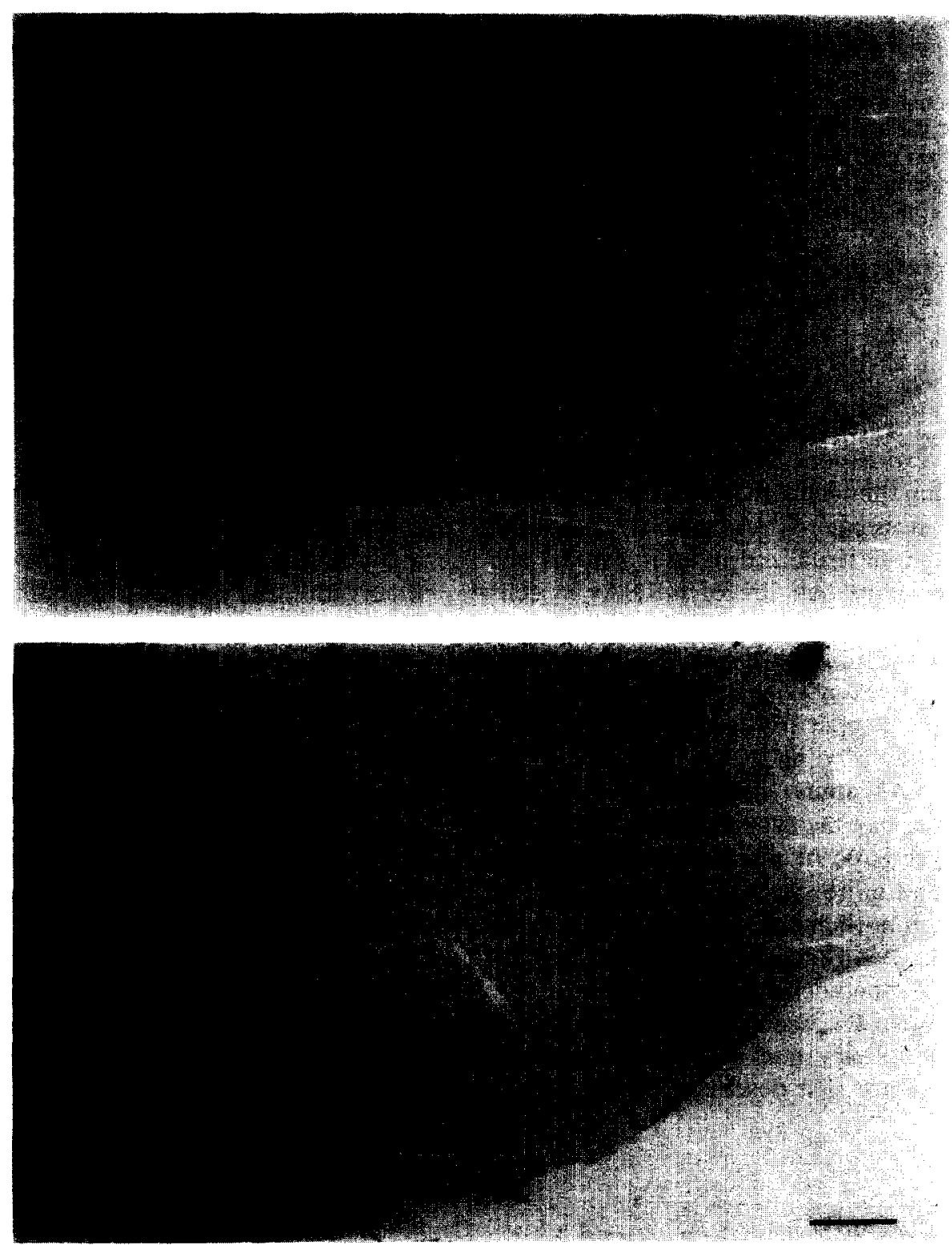

Fig. 1. (A,B): Sections $(18 \mu \mathrm{m})$ through rat superior olivary complex stained for presence of preproenkephalin mRNA by alkaline-phosphatase in situ method utilizing cRNA probe. Staining is in the ventral nucleus of the trapezoid body (VNTB). Scale bar $=100 \mu \mathrm{m}$. 
ods. This is of particular interest in light of the initial reports of enkephalin-like immunoreactivity in medial olivocochlear fibers in guinea pig (Fex and Altschuler, 1981; Eybalin et al., 1982, 1984), and the current consensus that opioid peptides are seen in the lateral system only (Altschuler et al., 1986; Eybalin and Pujol, 1989; Hoffman, 1986).

\section{Materials And Methods}

Pentobarbital-anesthetized animals were transcardially perfused sequentially with cold phosphate- buffered saline, $4 \%$ acetate-buffered paraformaldehyde, $\mathrm{pH} 6.5$, and then $4 \%$ tetraborate-buffered paraformaldehyde, $\mathrm{pH}$ 9.5. Specimens were post-fixed overnight in $4 \%$ tetraborate-buffered paraformaldehyde, $\mathrm{pH} 9.5$ with $10 \%$ sucrose. Cryostat sections (18 $\mu \mathrm{m})$ of brain were mounted onto Fisher Superfrost Plus slides. Sections are stored under dust-free conditions in slide boxes with dessicant at $-70^{\circ} \mathrm{C}$ until use.

Complementary DNA clones were used to generate cRNA probes for use in in situ hybridizations, using published methods (Deneris et al., 1988). Sense and antisense RNA probes (935 bases) corresponding to the entire coding region of the preproenkephalin gene
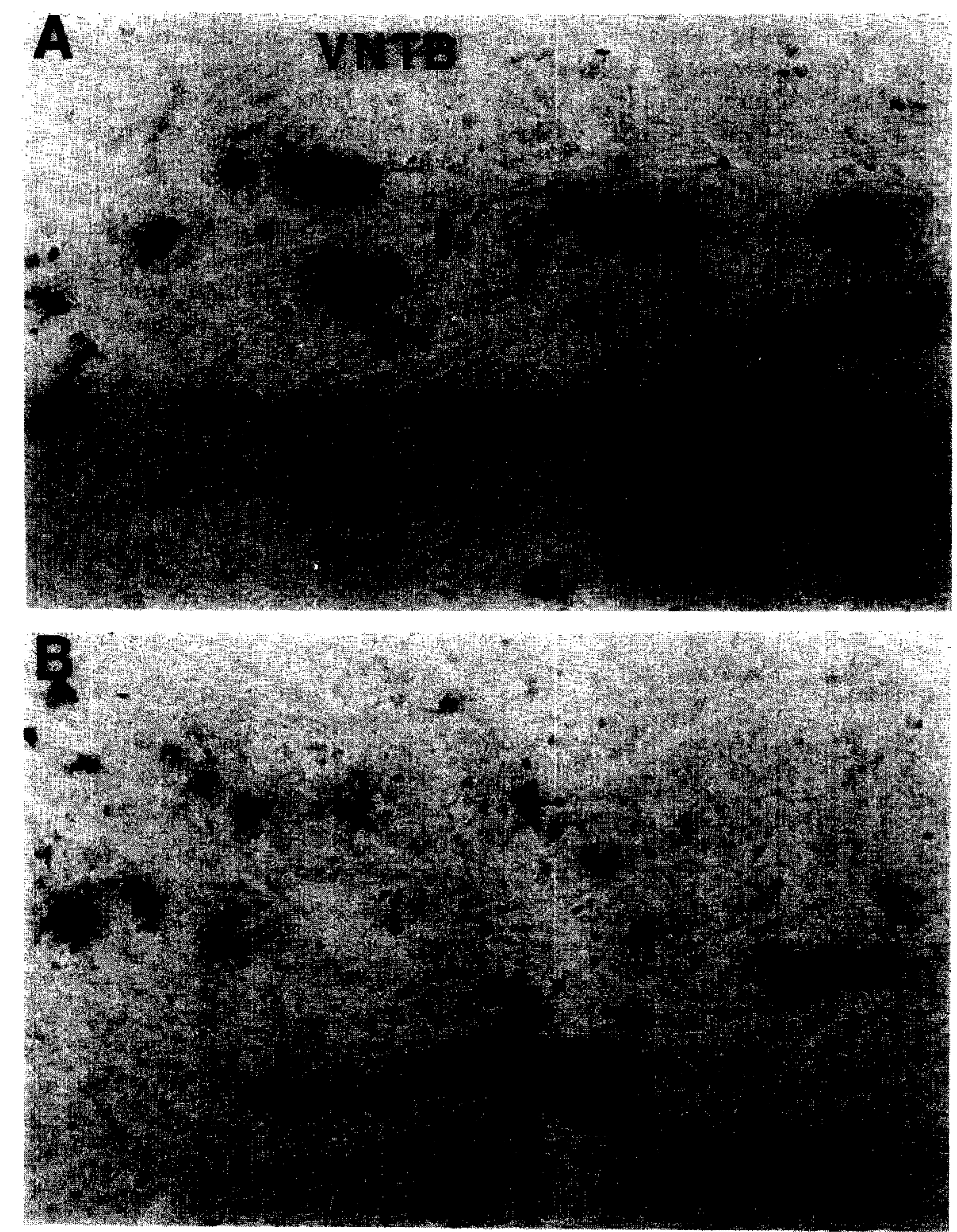

Fig. 2. (A,B): Sections $(18 \mu \mathrm{m})$ through rat pontine olivary region stained for presence of preproenkephalin mRNA by alkaline-phosphatase in situ method utilizing cRNA probe. Cytoplasmic labelling of stellate cells in the ventral nucleus of the trapezoid body is observed. Scale bars $=25 \mu \mathrm{m}$. 
(Sabol et al., 1983; gift of Dr. Steven Sabol) were generated using the SP6 RNA polymerase promoter, in the presence of digoxigenin-UTP. The sense probes were also labeled with digoxigenin and were used as negative controls for the in situ hybridization experiments. Additional control experiments were performed by treating sections with RNAase prior to applying the antisense probes.

Cryostat sections of paraformaldehyde-fixed tissue were prehybridized for in situs with riboprobes by $0.001 \%$ proteinase $\mathrm{K}$ digestion at $37^{\circ} \mathrm{C} \times 15 \mathrm{~min}$ in a Tris buffer. A longer digestion is used than with oligonucleotide probes in order to improve penetration of the larger riboprobes without resorting to alkaline hydrolysis of the riboprobes. Brief rinses in diethylpyrocarbonate treated water $\left(D E P C \mathrm{H}_{2} \mathrm{O}\right)$, and then $0.1 \mathrm{M}$ triethanolamine were performed, followed by acetic anhydride acetylation. Sections were then rinsed in ethanol, DEPC $\mathrm{H}_{2} \mathrm{O}$ and then $2 \times$ SSC washes $(3 \times 3 \mathrm{~min})$.

Sections were covered with hybridization probe solution and incubated in a closed, humidified container in a waterbath for $16-20$ hours at $56^{\circ} \mathrm{C}$. After hybridization, slides were washed twice in $50 \%$ formamide at $52^{\circ} \mathrm{C}$, then rinsed twice with $2 \times \mathrm{SSC}$ for 1 min. RNAase A $\left(30 \mathrm{~min}\right.$ at $\left.37^{\circ} \mathrm{C}\right)$ is used to remove unhybridized labeled RNA, and the sections were then rinsed twice in $2 \times \mathrm{SSC}$ for $1 \mathrm{~min}$, and then $50 \%$ formamide at $52^{\circ} \mathrm{C}$ for $5 \mathrm{~min}$. Sections were rinsed overnight in Triton $\mathrm{X}-100$ and normal sheep serum.

After hybridization with the digoxigenin-labeled probe and post-hybridization, sections were incubated for up to 5 hours with anti-digoxigenin Fab fragments coupled with a means of detection. For alkaline phosphatase-conjugated anti-digoxigenin Fab fragments, sections were incubated overnight with nitro-blue tetrazolium and levamisole, then rinsed to stop the color reaction. For fluorescence, sections were incubated with fluorescein- or rhodamine-coupled anti-digoxigenin Fab fragments. Slides were coverslipped in Aquamount without alcohol rinses, to avoid leaching of the alkaline phosphatase reaction product.

We have not found it necessary to use alkaline hydrolysis to shorten the probes in order to improve their penetration into cells. Full length riboprobes provide an excellent signal with high specificity. They can be labeled to high specific activity with any of several labels. Riboprobes bind more tightly than oligonucleotides as they bind at more base pairs, and because RNA/RNA pairs hybridize better than RNA/DNA

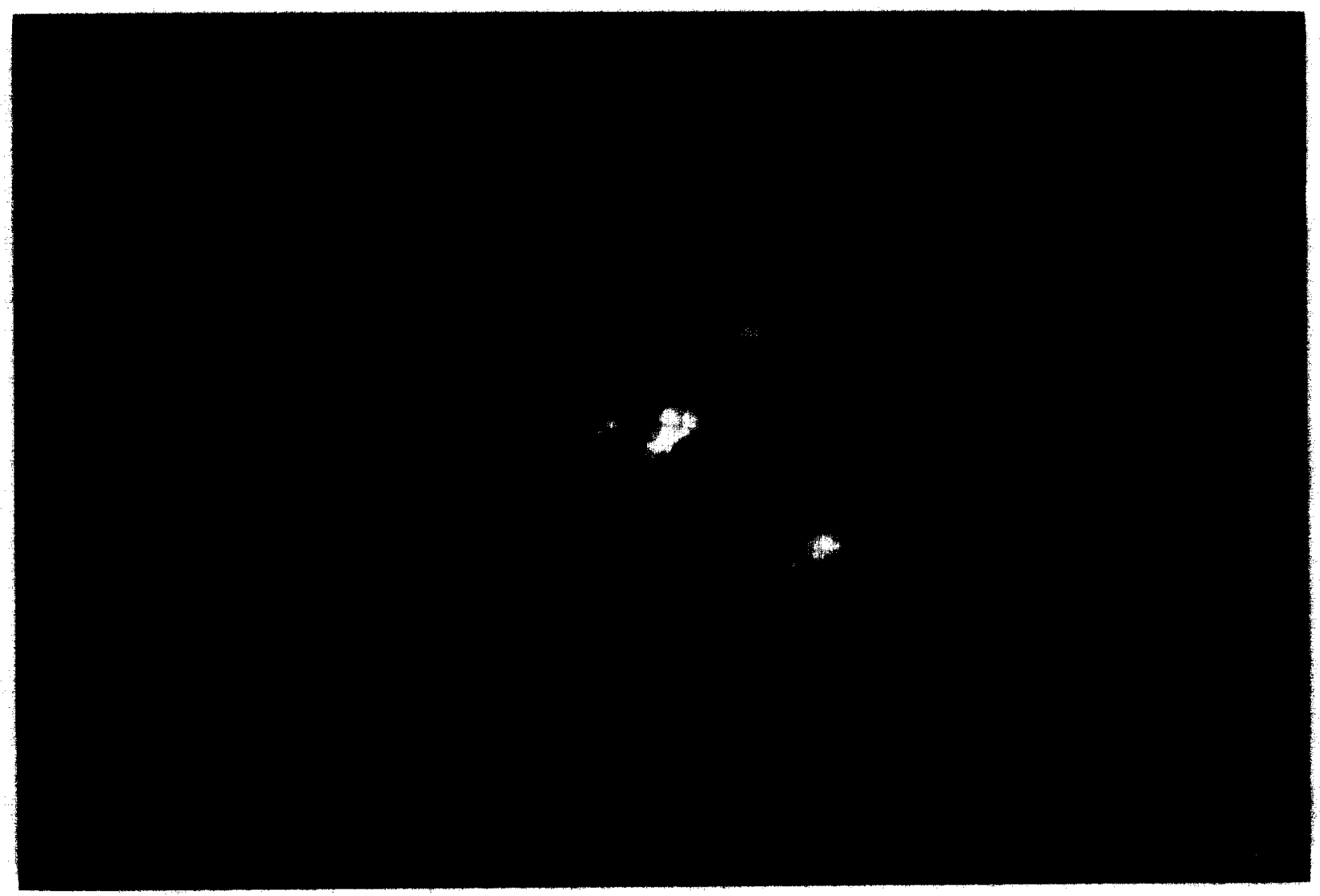

Fig. 3. Section (18 $\mu \mathrm{m}$ ) through rat pontine olivary region stained for presence of preproenkephalin mRNA by fluorescein-coupled in situ method utilizing cRNA probe. Highly fluorescent puncta surrounding nuclei may indicate subcellular localization of ribosomes in rough endoplasmic reticulum, where mRNAs would concentrate. Scale bar $=5 \mu \mathrm{m}$. 


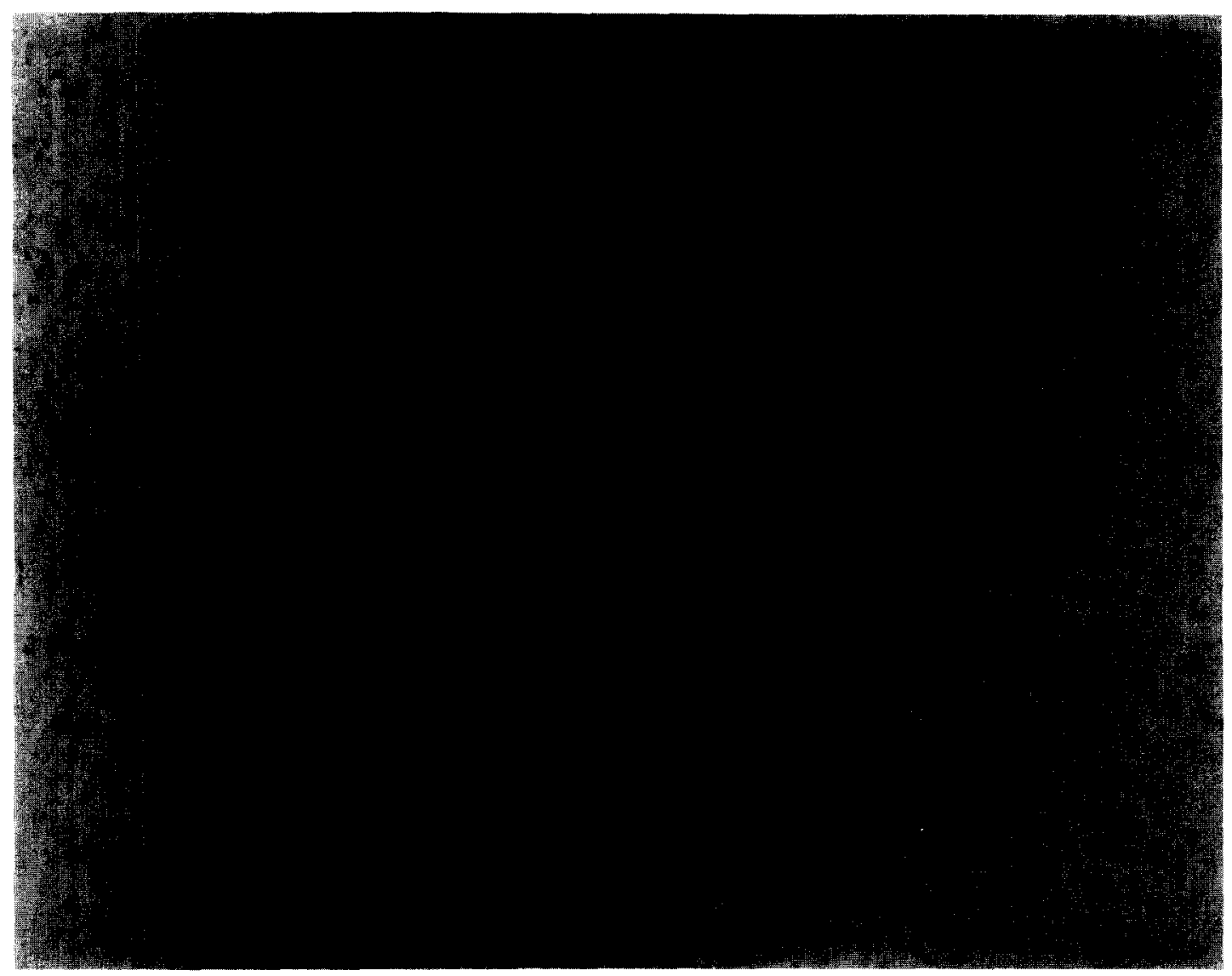

Fig. 4. Section $(18 \mu \mathrm{m})$ of rat brain at level of superior olivary complex, stained for presence of preproenkephalin mRNA by alkaline-phosphatase in situ method utilizing cRNA probe. No positive cells are seen in region of lateral superior olive (LSO). Scale bar $=100 \mu \mathrm{m}$.

pairs. They are also used more successfully across species, when hybridization and wash conditions are appropriately adjusted for differences in cRNA/ mRNA complementarity. All the advantages of cRNA probes apply equally well to radioactively-labeled and nonradioisotopically-labeled probes. Background staining in control sections with nonradioisotopically-labeled probes was very low. All uses and care of animals in the studies reported here were reviewed and approved by the Institutional Animal Care and Use Committee of Dartmouth College.

\section{Results}

Sections shown in the figures are representative of results from 5-6 animals. Control sections were run together with all experimental sections. No labeled cells were seen in sections incubated with RNAase prior to hybridization or when labeled sense probe controls were used (not shown).

\section{Superior olivary complex}

In the superior olivary complex, enkephalin-positive cells were confined to the ventral nucleus of the trapezoid body (VNTB; Fig 1A,B). Not all cells of the
VNTB were labeled, with the percentage varying in the rostral-caudal dimension, with the percentage lowest in the middle and higher more rostrally and caudally. Labeled cells were more evenly distributed along the medial-lateral axis. In alkaline-phosphatase stained material the reaction product often filled the entire somata, while the nucleus was unstained (Fig. 2A,B). While fixation and processing required by the in situ procedure resulted in some shrinkage and distortion, most cells tended to have a stellate shape and were largely medium sized (Fig. 2A,B, Fig. 3). Their appearance and distribution were consistent both with olivocochlear neurons and with the separate class of neurons whose major projection is to cochlear nucleus. In fluorescent stained material (Fig. 3) staining also was seen in the cytoplasm and was absent in nuclei. Highly fluorescent punta surrounding the dark nuclei might indicate subcellular organelles where mRNAs would be likely to be concentrated, such as rough endoplasmic reticulum. No enkephalin-positive neurons were observed in the lateral superior olive (Fig. 4).

\section{Cochlear nucleus}

Enkephalin-positive small cells were seen in the deep layer of the dorsal cochlear nucleus (Fig. 5A,B). A small number of enkephalin-positive cells were seen 

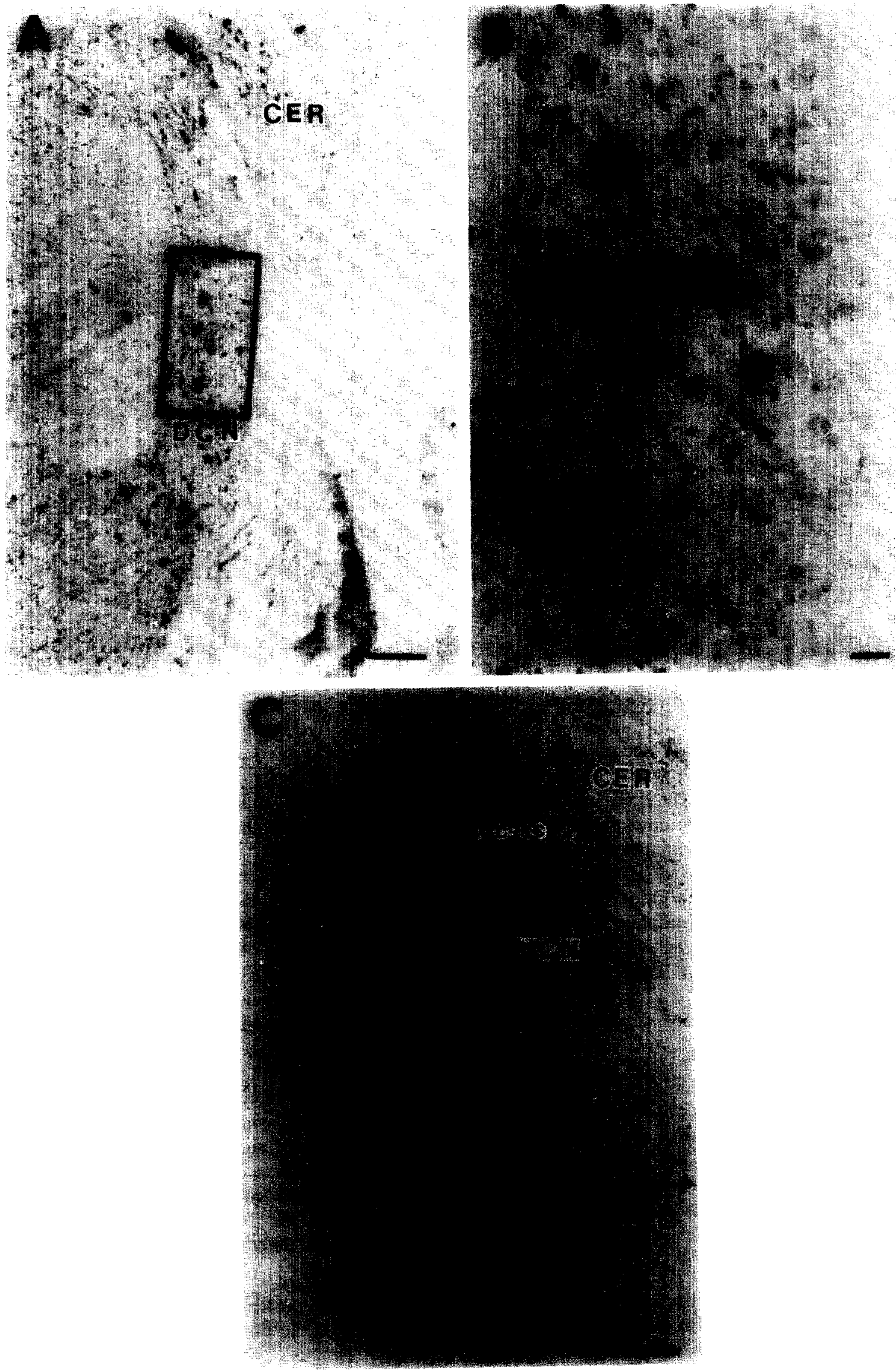
in the body of the ventral cochlear nucleus, mostly in the more rostral regions. Many enkephalin-positive small cells were seen in the granule cell/small cell region of the ventral cochlear nucleus (Fig. 5C). Cells in the cochlear nucleus, as in the VNTB, had their somata filled with stain reaction product, with no staining evident over cell nuclei, except for the nucleolus.

\section{Discussion}

Information transfer in auditory pathways depends on the interactions of neurotransmitters and receptors. Molecular biological techniques provide new and powerful tools for probing how such information is communicated from the hair cell to the auditory nerve, and from the efferent terminal to an afferent dendrite or hair cell. This technique can also be used to study stimulus-induced changes in transmitters and receptors and therefore provide insight into their function. Because the half-lives of mRNAs are so short (often 15 minutes or less), in situ hybridization can provide a temporally restricted snapshot of the expression of specific genes in individual cells.

Our results in rat are similar to those of Ryan et al. (1991) in the gerbil, but differ from the immunochemical results seen in the guinea pig by several groups (Altschuler et al., 1983, 1984; Abou-Madi et al., 1987; Eybalin et al., 1982, 1984; Fex and Altschuler, 1981). Our own preliminary data from in situ hybridization studies in guinea pig demonstrated positive cells in the lateral superior olive itself, which corresponds to the results of immunochemical studies. Can the preproenkephalin mRNA-expressing cells in the rat be the cells of origin of medial efferents, which are not now believed to contain enkephalins? (Altschuler et al., 1986; Eybalin and Pujol, 1989; Hoffman et al., 1984). Or are they cells of origin of lateral efferents, which must then have a very different anatomy and chemical anatomy in the rat than in the guinea pig? It must also be considered that these cells may not be part of an olivocochlear system. We may note here that calcitonin gene-related peptide (CGRP) terminals on outer hair cells in the rat do not arise in the VNTB, and the CGRP-immunoreactive cells in the rat VNTB do not project to the cochlea (Vetter et al., 1991). More extensive comparative studies with tract-tracing can clarify the origin of the opioid-expressing cochlear efferents in these different species, as well as the terminations of enkephalin-positive cells in rat VNTB.
The inability to visualize preproenkephalin gene expression in lateral superior olivary complex may reflect a very low constitutive level of gene expression in the absence of stimulation, which then implies that the level of olivocochlear neuropeptide gene expression may be to a great extent activity-driven. Unstimulated expression may be below the level of detection in somata with even the very sensitive in situ method, as it can be in immunocytochemical studies performed in rats that are not colchicine-pretreated. This point may be compounded if a significant amount of the enkephalin-immunoreactivity seen in lateral efferent terminals is actually leu-enkephalin cleaved from a dynorphin precursor (Zamir et al, 1984). Dynorphin-related neuropeptides have been shown to be present in lateral olivocochlear efferents (Altschuler et al., 1985, 1988; Hoffman et al., 1985), and the high ratio of leu-enkephalin:met-enkephalin in cochlea (Hoffman et al., 1983, 1984, 1985) could support some production of leu-enkephalin via this route.

In the cochlear nucleus, enkephalin-positive cells in dorsal cochlear nucleus (DCN) are seen, as has been reported previously using immunochemical techniques (Hokfelt et al., 1977). However, the positively staining cells in the granule cell-small cell region of ventral cochlear nucleus (VCN) have not been reported before. The in situ technique may be better adapted to identify neuropeptidergic cell bodies than is immunocytochemistry, which identifies peptide products that may require processing in nerve terminals. Another factor in this difference may be related to activity of the cells in expressing neuropeptide transmitter mRNA.

Neurotransmitter-related gene expression increases in neurons that are physiologically stimulated in response to activity-induced neurotransmitter depletion. These changes in the levels of gene expression for olivocochlear transmitters can be used to map the functional responses of olivocochlear neurons to specific auditory stimuli. The considerable distance between olivocochlear somata and their terminations in the organ of Corti makes the peripheral auditory system an excellent model in which to study this functional regulation of neuropeptide gene expression. A more quantitative description of the distribution of peptide-expressing olivocochlear cells, and the level of expression of neuropeptide message as a function of auditory stimulation, awaits a more formal mapping study. This information has important consequences for future therapeutic interventions in auditory dysfunctions which involve neurotransmission in auditory

Fig. 5. Sections $(18 \mu \mathrm{m})$ of rat cochlear nucleus stained for presence of preproenkephalin mRNA by alkaline-phosphatase in situ method utilizing cRNA probe. (A): stained cells in deep layer of dorsal cochlear nucleus (DCN). (B): higher magnification demonstrates cellular localization of staining. (C): staining in ventral cochlear nucleus (VCN) is largely confined to granule cell-small cell region (gc-sc). CER, cerebellum. Scale bars $=100 \mu \mathrm{m}$ (A and $\mathrm{C}$ ) and $25 \mu \mathrm{m}$ (B). 
pathways. Of especial interest is the potential role of auditory neuronal activity in modulating the expression of neuropeptide mRNA in olivocochlear pathways, and the use of the in situ hybridization method to map the physiological responses of olivocochlear neurons to auditory stimulation.

\section{Acknowledgements}

We thank the Hitchcock Foundation, the Waterhouse Foundation, the Norris Cotton Cancer Center Student Assistantship program, NIEHS grant ES 07104 (Roger Smith) and NIDCD grant DC00383 (RAA) for their support, and Dr. Sabol for the preproenkephalin probe.

\section{References}

Abou-Madi, L., Pontarotti, P., Tramu, G., Cupo, A. and Eybalin, M. (1987) Coexistence of putative neuroactive substances in lateral olivocochlear neurons in guinea pig and rat. Hear. Res. 30, 135-146.

Adams, J.C., Mroz, E.A. and Sewell, W.F. (1987) A possible neurotransmitter role for CGRP in a hair-cell sensory organ. Brain Res. 419, 347-351.

Altschuler, R.A. and Fex, J. (1986) Efferent neurotransmitters. In: R.A. Altschuler, R.P. Bobbin and D.W. Hoffman (Eds.), Neurobiology of Hearing, Raven Press, New York, pp. 383-396.

Altschuler, R.A., Fex., J., Parakkal, M.H. and Eckenstein, F. (1984) Co-localization of enkephalin-like and choline acetyltransferaselike immunoreactivities in olivocochlear neurons of the guinea pig. J. Histochem. Cytochem. 32, 839-843.

Altschuler, R.A., Hoffman, D.W., Reeks, K.A. and Fex, J. (1985) Immunocytochemical localization of dynorphin B-like and alphaneoendorphin-like immunoreactivities in the guinea pig organ of Corti. Hear. Res. 17, 249-258.

Altschuler, R.A., Parakkal, M.H. and Fex J. (1983) Localization of enkephalin-like immunoreactivity in acetylcholinesterase-positive cells in the guinea pig lateral superior olivary complex that project to the cochlea. Neuroscience 9, 621-630.

Altschuler, R.A., K.A. Reeks, J. Fex and Iloffman, D.W. (1988) Lateral olivocochlear neurons contain both enkephalin and dynorphin immunoreactivities: immunocytochemical co-localization studies. J. Histochem. Cytochem. 36, 797-801.

Altschuler, RA, RJ Wenthold, DW Hoffman and J Fex. (1986) Neurotransmitters of the cochlea and cochlear nucleus: Immunocytochemical evidence. Am. J. Otolaryngol. 7, 100-106.

Art, J.J. and Fettiplace, R. (1984) Efferent desensitization of auditory nerve fibre responses in the cochlea of the turtle pseudemys scripta elegans. J. Physiol. 356, 507-523.

Deneris, E.S., Connolly, J., Boulter, J., Wada, E., Wada, K., Swanson, L.W., Patrick, J. and Heinemann, S. (1988) Primary structure and expression of b2: a novel subunit of neuronal nicotinic acetylcholine receptors. Neuron 1, 45-54.

Eybalin, M., Christolomme, A., Gavioli, M., Pradelles, P., Calas, A. and Pujol, J. (1982) Enkephalin-like substances in the cochlea: Further investigations. Neurosci. Lett., 10, S166-S167 (Abstr.)

Eybalin, M., Cupo, A.A. and Pujol, R. (1984) Met-enkephalin characterization in the cochlea: High performance liquid chromatography and immunoelectron microscopy. Brain Res., 305, 313-322.
Eybalin M and Pujol R (1989) Cochlear neuroactive substances. Arch. Oto-rhino-laryngol. 246, 228-234.

Fex, J. (1968) Efferent inhibition in the cochlea by the olivocochlear bundle. In: A.V.S. de Reuck and J. Knight (Eds.), Ciba Foundation Symposium on Hearing Mechanisms in Vertebrates. J.A. Churchill, London pp. 169-181.

Fex, J. and Altschuler, R.A. (1981) Enkephalin-like immunoreactivity of olivocochlear nerve fibers in cochlea of guinea pig and cat. Proc. Nat. Acad. Sci. USA 78, 1255-1259.

Gifford, M.L. and Guinan, J.J. (1987) Effects of electrical stimulation of medial olivocochlear neurons on ipsilateral and contralateral cochlear responsess. Hear. Res. 29, 179-194.

Guinan, J.J. and Gifford, M.L. (1988a) Effects of electrical stimulation of efferent olivocochlear neurons on cal auditory-nerve libers. I. Rate-level functions. Hear. Res. 33, 97-114.

Guinan, J.J. and Gifford, M.L. (1988b) Effects of electrical stimulation of efferent olivocochlear neurons on cat auditory-nerve fibers. II. Spontaneous rate. Hear. Res. 33, 115-128.

Guinan, J.J. and Gifford, M.L. (1988c) Effects of electrical stimulation of efferent olivocochlear neurons on cat auditory-nerve fibers. III. Tuning curves and thresholds at CF. Hear. Res. 37, 29-45.

Guinan, J.J., Warr, W.B. and Norris, B.E. (1983) Differential olivocochlear projections from lateral versus medial zones of the superior olivary complex. J. Comp. Neurol., 22l, 358-370.

Guinan, J.J., Warr, W.B. and Norris, B.E. (1984) Topographic organization of the olivocochlear projections from the lateral and medial zones of the superior olivary complex. J. Comp. Neurol. 226, 21-27.

Hoffman, D.W. (1986) Opioid mechanisms in the inner ear. In: R.A. Altschuler, R.P. Bobbin and D.W. Hoffman (Eds.), Neurobiology of Hearing, Raven Press, New York, pp. 371-382.

Hoffman, D.W., Altschuler, R.A. and Fex, J. (1983) High performance liquid chromatographic identification of enkephalin-like peptides in the cochlea, Hear. Res. 9, 71-79.

Hoffman, D.W., Rubio, J.A., Altschuler, R.A. and Fex, J. (1984) Several distinct receptor binding enkephalins in olivocochlear fibers and terminals in the organ of Corti. Brain Res. 322, 59-65.

Hoffman, D.W., Zamir, N., Rubio, J.A., Altschuler, R.A. and Fex J. (1985) Proenkephalin and prodynorphin derived peptides in olivocochlear fibers of the auditory system. Hear. Res. 17, 47-50.

Hokfelt, T., Elde, R., Johansson, O., Terenius, L. and Stein, L. (1977) The distribution of enkephalin-immunoreactive cell bodies in the rat central nervous system. Neurosci. Lett. 5, 25-31.

Liberman, M.C. (1988) Rapid assessment of sound-evoked olivocochlear feedback: suppression of compound action potential by contralateral sound. Hear. Res. 38, 47-56.

Liberman, M.C. (1989) Effects of chronic cochlear de-efferentation on auditory-nerve response. Hcar. Res. 49 209-224.

Liberman, M.C. (1991) The olivocochlear efferent bundle and susceptibility of the inner ear to acoustic injury. J. Neurophysiol. 65, 123-132.

Liberman, M.C. and Brown, M.C. (1988) Physiology and anatomy of single olivocochlear neurons in the cat. Hear. Res. 24, 17-36.

Lu, S.M., Schweitzer, L., Cant, N.B. and Dawbarn, D. (1988) Immunoreactivity to calcitonin gene-related peptide in the superior olivary complex and cochlea of cat and rat. Hear. Res. 31, $137-146$

Rajan, R. and Johnstone, B.M. (1988) Binaural acoustic stimulation exercises protective effects at the cochlea that mimic the effects of electrical stimulation of an auditory efferent pathway. Brain Res. 459, 241-255.

Rasmussen, G.L. (1942) An efferent cochlear bundle. Anat. Rec. 82, 441.

Rasmussen, G.L. (1946) The olivary peduncle and other fiber projections of the superior olivary complex. J. Comp. Neurol. 84, 141-219.

Ryan, A.F., Simmons, D.M., Watts, A.G. and Swanson, L.W. (1991) 
Enkephalin mRNA production by cochlear and vestibular efferent neurons in the gerbil brainstem. Exp. Brain Res. 87, 259-267.

Sabol, S.L., Yoshikawa, K. and Hong, J.-S. (1983) Regulation of methionine-enkephalin precursor messenger RNA in rat striatum by haloperidol and lithium. Biochem. Biophys. Res. Comm. 113, 391-399.

Sahley, T.L, Kalish, R.B, Musiek, F.E. and Hoffman, D.W. (1991) Effects of opioid drugs on auditory evoked potentials suggest a role of lateral olivocochlear dynorphins in auditory function. Hear. Res. 55, 133-142.

Vetter, D.E., Adams, J.C. and Mugnaini, F. (1991) Chemically distinct rat olivocochlear neurons. Synapse 7, 21-43.

Warr, W.B. (1980) Efferent components of the auditory system. Ann. Otorhinolaryngol. 89, Supplement 74, 114-120.

Warr, W.B. and Guinan, J.J. (1979) Efferent innervation of the organ of Corti: two separate systems. Brain Res. 173, 152-155.
Warr, W.B., Guinan, J.J. and White, J.S. (1986) Organization of the efferent fibers: The lateral and medial olivocochlear systems. In: R.A. Altschuler, R.P. Bobbinn and D.W. Hoffman (Eds.), Neurobiology of Hearing, Raven Press, New York, pp. 333-348.

Wiederhold, M.L. (1986) Physiology of the olivocochlear system, In: R.A. Altschuler, D.W. Hoffman and R.P. Bobbin (Eds.), Neurobiology of Hearing, Raven Press, New York, pp. 349-370.

Winslow, R.L. and Sachs, M.B. (1987) Effect of electrical stimulation of the crossed olivocochlear bundle on auditory nerve response to tones in noise. J. Neurophysiol. 57, 1002-1021.

Winter, I.M., Rohertson, D. and Cole, K.S. (1989) Descending projections from auditory brainstem nuclei to the cochlea and cochlear nucleus of the guinea pig. J. Comp. Neurol. 280, 143-157.

Zamir, N., Palkovits, M., Weber, E., Mezey, E. and Brownstein M.J. (1984) A dynorphinergic pathway of leu-enkephalin production in rat substantia nigra. Nature 307, 643-645. 